\title{
HIGH-STRAIN-RATE FORMING PERFORMANCE OF AN ALUMINUM ALLOY
}

\author{
ZNAČILNOSTI ZELO HITREGA ELEKTROMAGNETNEGA \\ PREOBLIKOVANJA ALUMINIJEVE ZLITINE
}

\author{
Feixiang Jin*, Man Gu, Hua Zhong \\ School of Mechanical Engineering, Hefei University, 158 Jinxiu Avenue, Shushan district, Hefei City, 230601, China \\ Prejem rokopisa - received: 2019-09-20; sprejem za objavo - accepted for publication: 2020-06-17
}

doi:10.17222/mit.2019.255

\begin{abstract}
The forming performance of an AA6014 aluminum alloy sheet at a high strain rate was studied. An electromagnetic forming test and LS-DYNA software were used to study the plastic deformation process of 1-mm-thick aluminum alloy plates at different voltages. The results showed that the maximum strain rate of the aluminum alloy plate reached $10^{4} \mathrm{~s}^{-1}$, the maximum speed of the plate center was $382.32 \mathrm{~m} / \mathrm{s}$, the swelling depth test result was $49.608 \mathrm{~mm}$, the simulation result was $48.25 \mathrm{~mm}$, the thickness test result was $0.71 \mathrm{~mm}$, and the simulation result was $0.696 \mathrm{~mm}$ under a voltage of $4 \mathrm{kV}$ and a capacitance of $2400 \mu \mathrm{F}$. The test results were close to the simulation findings. The analysis of the electromagnetic forming test and the simulation results showed that the strain rate, sheet-metal bulging depth, and forming performance of the aluminum alloy improved gradually with an increased voltage, whereas the minimum thickness gradually decreased. The forming performance of the aluminum alloy sheet under different high strain rates was studied. The effect of high strain rate on the forming performance of the aluminum alloy sheet was obtained by a comparison between the test and simulation results. Theoretical guidance was further provided for the development of the forming technology of the aluminum alloy sheet.
\end{abstract}

Keywords: high strain rate, aluminum alloy, electromagnetic forming, finite-element simulation

Avtorji v pričujočem članku opisujejo študijo zelo hitrega preoblikovanja pločevine iz Al zlitine AA6014. Hitro preoblikovanje so izvajali z elektromagnetnim postopkom preoblikovanja pri različnih električnih napetostih (jakostih magnetnega polja) in uporabljali računalniško programsko opremo LS-DYNA za študij plastične deformacije plošč debeline en (1) mm. Rezultati eksperimentov so pokazali, da je bila dosežena maksimalna hitrost deformacije izbrane Al zlitine $10^{4} \mathrm{~s}^{-1}$, maksimalna hitrost potovanja sredine trna/plošče je bila $382,32 \mathrm{~m} / \mathrm{s}$, pri tem pa je bila vdorna globina preizkusnega trna $49,608 \mathrm{~mm}$, debelina deformirane pločevine pa $0,71 \mathrm{~mm}$. Z računalniško simulacijo so dobili naslednje vrednosti: za vdorno globino: $48,25 \mathrm{~mm}$ in debelino pločevine: $0,696 \mathrm{~mm}$. V tem primeru so elektromagnetno preoblikovanje izvajali pri napetosti $4 \mathrm{kV}$ in kapacitivni upornosti $2400 \mu \mathrm{F}$. Kot kažejo rezultati računalniških simulacij, so se le-ti dobro ujemali z eksperimenti. Analiza elektromagnetnega preoblikovanja in rezultati simulacij so pokazali, da se hitrost deformacije in vdorna globina postopno povečujeta, medtem ko se debelina pločevine zmanjšuje. Na osnovi te študije so avtorji pripravili teoretično podlago za nadaljnji razvoj tehnologije hitrega elektromagnetnega preoblikovanja Al zlitin.

Ključne besede: velika hitrost deformacije, aluminijeva zlitina, elektromagnetno preoblikovanje, simulacija na osnovi metode končnih elementov

\section{INTRODUCTION}

Aluminum alloys are some of the ideal materials for lightweight products. ${ }^{1}$ An aluminum alloy has the advantage of low density, high specific strength and stiffness, good elasticity and impact resistance, good processing formability, and considerable recycling capability. Aluminum alloys have been widely used in traditional high-end fuel and new electrical vehicles. W.Y. $\mathrm{Ma}^{2} \mathrm{ob}-$ served the poor forming performance of an aluminum alloy in the traditional plastic forming; local cracking and rebound defects can also be easily produced. Rebound is difficult to avoid during the traditional stamping of an aluminum alloy. F. C. Salvado ${ }^{3}$ observed the inertial thinning caused by the high-speed impact of molds, changes in the material's constitutive relationship and the plastic deformation mechanism at high rates, and improved forming performance of the aluminum alloy materials

*Corresponding author's e-mail:

brimetamtejfx@163.com (Feixiang Jin) and aluminum alloy plates due to high-strain-rate forming during the deformation. Cracking defects and rebound are effectively suppressed. However, this previous research focused only on the effects of the constitutive relationship. G. K. Dhiraj ${ }^{4}$ described several products with complex structures that are easily formed at high speed. The forming effect far exceeds the traditional quasi-static forming process. A.V. Mamutov ${ }^{5}$ reported that electromagnetic forming is a high-strain-rate forming process. Electromagnetic forming has the advantages of inhibiting wrinkles, reducing rebounds, high forming limits, easy energy control, and production automation. Numerical simulation results were obtained using the finite-element software LS-DYNA. However, Mamutov performed no comparison with the results of experiments. V. J. Vohnout et al. ${ }^{6}$ consist of the research team of Professor Deahn of Ohio State University in the United States; they pioneered the idea of magnetic pulse-assisted stamping forming technology in the international community and conducted innovative experi- 
mental research. C. F. $\mathrm{Li}^{7}$ conducted an electromagnetic-assisted tensile experiment on an AA5052-O aluminum alloy. The results showed that the electromagnetic-assisted tensile forming performance far exceeded the quasi-static forming performance, presenting a performance that is slightly higher than the electromagnetic drawing-deep-forming performance. However, Li did not consider the effects of different high strain rates. D. H. $\mathrm{Liu}^{8}$ used unidirectional tensile and bidirectional tensile methods to study the quasi-static and dynamic forming properties of AA5052 aluminum alloy plates. The results showed that the limits of the unidirectional tensile, plane strain, and double isotensile composite forming were significantly higher than the corresponding quasi-static forming limit under quasi-static-dynamic composite loading. Composite loading showed a slightly higher limit plastic strain level than complete dynamic loading. J. Imbert ${ }^{9}$ studied the electromagnetic forming of preformed AA5754 aluminum alloy plates by experimental and computational simulations. The results showed that electromagnetic forming significantly improved the forming limit performance of the AA5754 aluminum alloy plates. Deformation from a radius of $20 \mathrm{~mm}$ to $5 \mathrm{~mm}$ was achieved. J. Fang ${ }^{10}$ obtained 2.16-fold traditional stamping using an electromagnetic-assisted, progressive draw-forming method. R. Smerda ${ }^{11}$ performed dynamic tensile tests on AA5754 and AA5182 aluminum alloys. The tests were achieved using separate Hopkinson. The results showed that the strain-rate sensitivity was not obvious at strain rates of 600 /s to $1500 / \mathrm{s}$. The main reason is that the strain rate was small and remained below the critical strain rate. J. D. Thomas ${ }^{12}$ noted that material formability improved due to the strain rate sensitivity of the material and inertia during magnetic pulse forming. The limit curve of the electromagnetic forming of the aluminum tube was obtained. H.W. $\mathrm{Li}^{13}$ showed that the peak stress and electro-plasticity softening ratio increased with the increase in the electro-plastic energy density. A novel model for predicting the current-carrying dynamic behavior of an Al alloy was established. W.S. Lee ${ }^{14}$ showed that the strain-rate sensitivity of an AA6061-T6 aluminum alloy gradually increased with the increase in strain rate. The flow stress and strain-rate sensitivity increase with an increase in the strain rate or decrease in the temperature. The temperature sensitivity increases with the increase in the strain rate and the temperature. B. Ravindranadh ${ }^{15}$ reported that the formability of AA7017 aluminum alloys increased significantly with the increase in the strain rate. The Johnson-Cook $(\mathrm{J}-\mathrm{C})$ constitutive model was developed for AA7017 aluminum alloy on the basis of high-strain-rate tensile data generated from a split Hopkinson tension bar at various temperatures. However, a small high strain rate was used in the experimental research. K. Guo ${ }^{16}$ improved the forming depth of the slab and shape deviation of a mold using the method of continuous discharge with a small voltage for a fixed high-voltage position. The electromagnetic forming experiments and simulation results were compared and analyzed. P. Evandro ${ }^{17}$ revealed that the coupling of different currents, electromagnetic fields, and work pieces during electromagnetic forming influenced the prediction of the electromagnetic force. However, the thickness distribution results at different currents were not provided. Q. X. Zhang ${ }^{18}$ studied the deformation behavior of a large-size sheet metal under Lorentz force. The results showed that the height and area of the sheet-metal forming can be effectively controlled by changing the discharge voltage and position. The plastic deformation performance of the metal was significantly influenced by its deformation strain rate. In the present study, the deformation process and influence of the AA6014 aluminum alloy sheet for an automobile under different high strain rates were studied and analyzed by changing the voltage size. The theoretical basis for the development of the aluminum alloy sheet forming technology for automobiles is further provided.

\section{MATERIALS AND METHODS}

\subsection{Materials}

The test material was an AA6014 alloy plate with a thickness of $1 \mathrm{~mm}$ and its chemical composition is shown in Table 1. The electromagnetic forming test sheet size of $300 \mathrm{~mm} \times 300 \mathrm{~mm}$.

Table 1: Chemical composition of AA6014 aluminum alloy sheet (\%)

\begin{tabular}{|c|c|c|c|c|c|c|c|c|c|}
\hline $\mathrm{Si}$ & $\mathrm{Fe}$ & $\mathrm{Cu}$ & $\mathrm{Mn}$ & $\mathrm{Mg}$ & $\mathrm{Cr}$ & $\mathrm{Zn}$ & $\mathrm{Ti}$ & $\mathrm{V}$ & $\mathrm{Al}$ \\
\hline 0.59 & 0.22 & 0.12 & 0.08 & 0.65 & 0.01 & 0.01 & 0.03 & 0.01 & bal. \\
\hline
\end{tabular}

\subsection{Test methods}

The flat electromagnetic forming experiment device used in the test (Figure 1) had a coil radius of R140 mm,

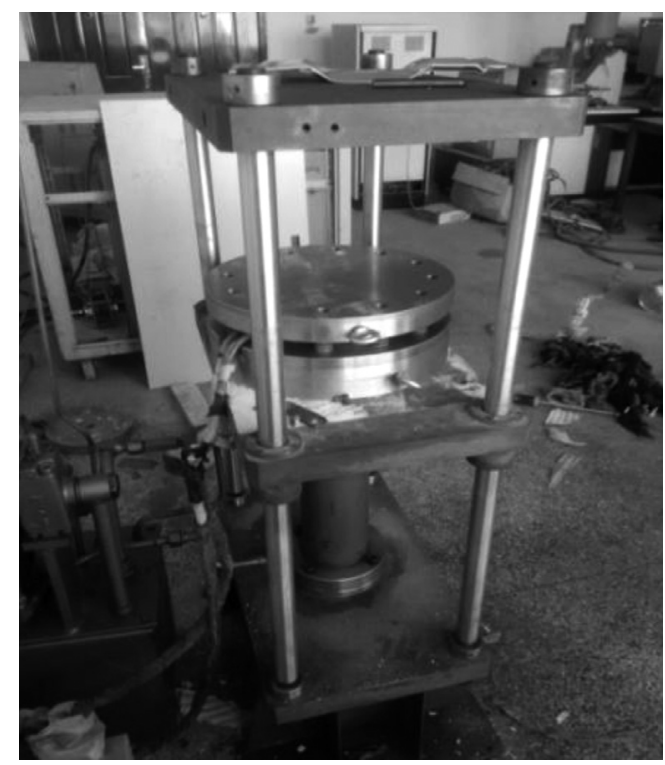

Figure 1: Devices used in the experiments 


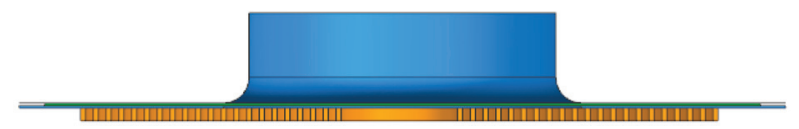

Figure 2: 3D geometric model of electromagnetic expansion

a concave die inner diameter of $120 \mathrm{~mm}$, a circular radius of $\mathrm{R} 10 \mathrm{~mm}$, and a distance of $1 \mathrm{~mm}$ between the coil and the plate. The deformation results of the aluminum alloy plates with different high strain rates were obtained by adjusting the voltage parameters. The test voltages were $(2.0,2.5,3.0,3.5$, and 4.0$) \mathrm{kV}$; the capacitance of the capacitor was $2400 \mu \mathrm{F}$. The plate material was placed on the press-driven coil. The mold pressed on the plate. The charging voltage of the capacitor was controlled, and an instantaneous discharge was triggered. At this point, the electromagnetic field force exceeded the yield strength of the aluminum alloy sheet material in several microseconds. Sheet plastic deformation was generated. Given the large diameter of the forming sheet, the sheet material was measured via a displacement gauge. Measurements were repeated five times to reduce the measurement error. The average depth of the sheet formed with different strain rates was obtained.

\subsection{Numerical model}

The electromagnetic forming simulation analysis of the aluminum alloy sheet material included electric, magnetic, and structural fields. LS-DYAN was used to perform multiphysical field coupling simulation analyses. To compare the simulation results with the experimental findings, we used the capacitance, voltage, inductance, and resistance values of the input experiment as the loads for the electromagnetic field analysis during the simulation. ${ }^{19}$ The flat electromagnetic expansion of the AA6014 aluminum alloy sheet was finished. Figure 2 shows the 3D geometric model and size of the electromagnetic expansion. The mold circular angle was $10 \mathrm{~mm}$, the flat coil turn number was 23 , the cross-sectional area was $1.5 \mathrm{~mm} \times 6 \mathrm{~mm}$, the coil closure spacing was $2 \mathrm{~mm}$, and the inductance was $2.75 \mu \mathrm{H}$. The sheet material diameter was $280 \mathrm{~mm}$, the plate thickness was 1 $\mathrm{mm}$, and the distance between the coil and sheet material was $1 \mathrm{~mm}$. The total resistance of the discharge loop was $25 \mathrm{~m} \Omega$. Table 2 shows the parameters of the electromagnetic expansion analysis of the flat plate helical coil and the aluminum alloy sheet.

Table 2: Electromagnetic forming parameters of aluminum alloy plates and coils

\begin{tabular}{|c|c|c|c|c|c|}
\hline Material & $\begin{array}{c}\text { Relative } \\
\text { perme- } \\
\text { ability }\end{array}$ & $\begin{array}{c}\text { Resistiv- } \\
\text { ity }(\Omega \cdot \mathrm{m})\end{array}$ & $\begin{array}{c}\text { Density } \\
\left(\mathrm{kg} / \mathrm{m}^{3}\right)\end{array}$ & $\begin{array}{c}\text { Poisson's } \\
\text { ratio }\end{array}$ & $\begin{array}{c}\text { Elastic } \\
\text { modulus } \\
(\mathrm{GPa})\end{array}$ \\
\hline $\begin{array}{c}\text { Alumi- } \\
\text { num alloy }\end{array}$ & 1 & $4.0 \mathrm{e}-8$ & 2700 & 0.33 & 69 \\
\hline Copper & 1 & $1.75 \mathrm{e}-8$ & 8900 & 0.34 & 113 \\
\hline
\end{tabular}

The grid model, current load, and boundary conditions of the entire electromagnetic forming simulation were established by LS-DYNA. Rigid shell units were used for the mold to reduce the calculation time. To improve the simulation accuracy, we used a hexahedral element to conduct the mesh division of the coil, sheet metal, and blank holder. The grid was divided by a scanning method. The $\mathrm{J}-\mathrm{C}$ constitutive model of dynamic plastic deformation was adopted as follows (Equation (1)): $:^{20}$

$\sigma=\left(123+441.58 \varepsilon^{0.60613}\right)\left(1-0.0041 \ln \dot{\varepsilon}^{*}\right)\left[1-\left(\frac{\Delta T}{630}\right)^{1.207}\right]$

\section{RESULTS AND DISCUSSION}

The simulation results of the deformation aluminum-alloy sheets under different high strain rates were obtained by adjusting the voltage of the electromagnetic forming. The electromagnetic expansion of the aluminum alloy plates was simulated using the voltages of $(2.0,2.5,3.0,3.5$, and 4.0$) \mathrm{kV}$. The electromagnetic expansion's maximum displacement and displacement increased with different voltages (Table 2). The displacement of the expansion shape of the aluminum alloys gradually increased with the increase in the voltage. The maximum displacement of the same position increased gradually with the voltage. As shown in Figure 3, the strain rate at the center of the sheet material changed with the time at different voltages. The high deformation speed increased gradually with the voltage. The maximum strain rate reached $10^{4} \mathrm{~s}^{-1}$ at $4 \mathrm{kV}$. The strain rate fluctuated considerably with the deformation of the sheet metal. This result was attributed to the constantly changing electromagnetic force, which was generated in different areas of the sheet metal, with the continuous deformation of the sheet metal, which resulted in a constant change in the local deformation velocity and the displacement of the sheet metal. Thus, the strain rate changed constantly during deformation. The maximum strain rate of the plate material increased continuously with the increase in the voltage. Figure 4 shows the electromagnetic expansion displacement distribution of the aluminum-alloy sheet test and the simulation with different voltages. The increase in electromagnetic expansion displacement of the aluminum alloy plates ws relatively close with the voltage.

Table 3 lists the measured results of the deformation depth of the sheet material. The experimental results showed that the electromagnetic forming depth increased with the increase in the voltage. This finding indicates that different drawing depth shapes can be obtained by changing the voltage size and shape of the mold. 

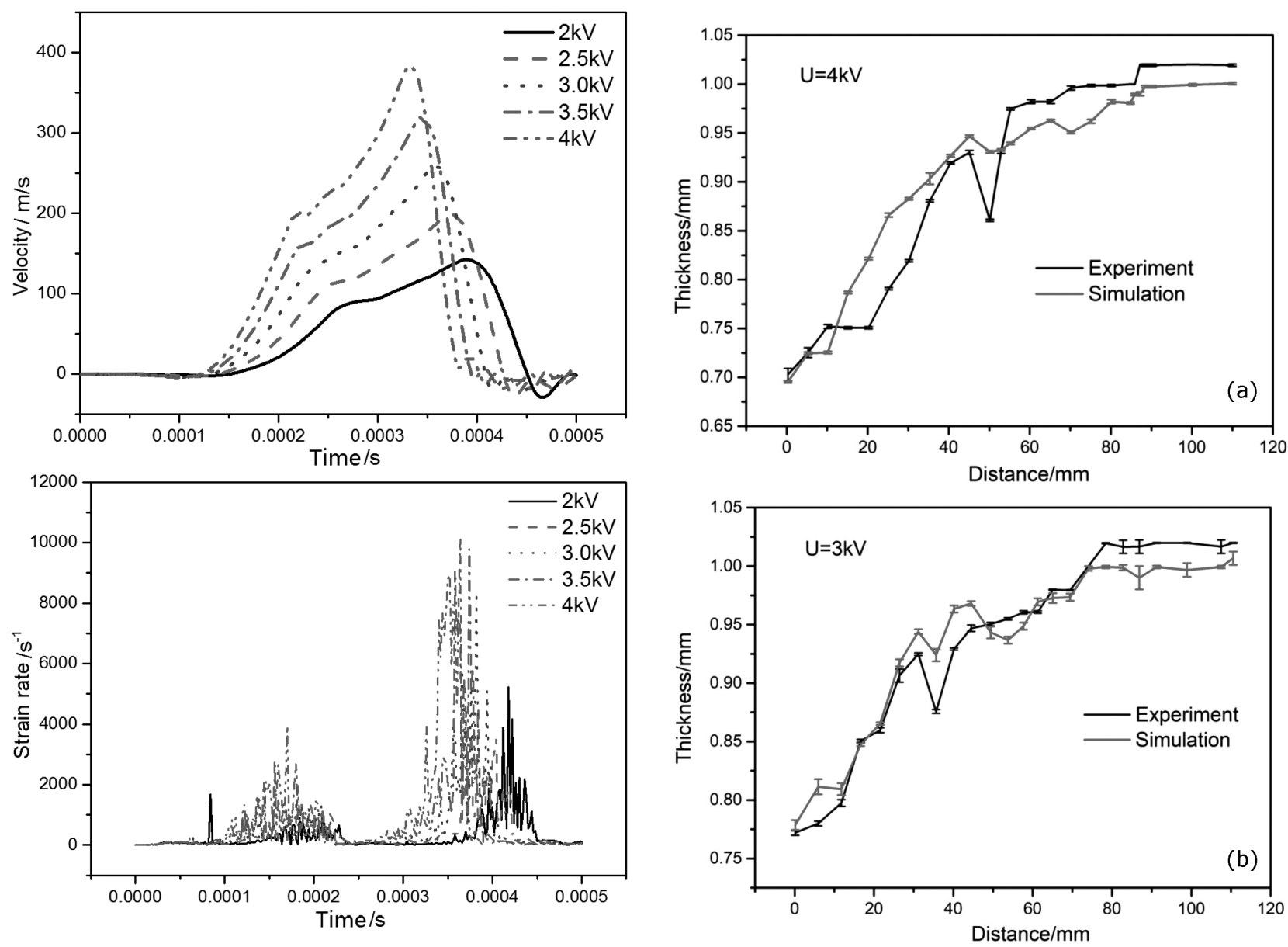

Figure 3: Changes in deformation speed and strain rate over time at different voltages: a) deformation speed, b) strain rates

Table 3: Maximum displacement of electromagnetic expansion and displacement increase at different voltages

\begin{tabular}{|l|c|c|c|c|c|}
\hline \multicolumn{1}{|c|}{ voltage /V } & 4 & 3.5 & 3 & 2.5 & 2 \\
\hline $\begin{array}{l}\text { simulation displace- } \\
\text { ment /mm }\end{array}$ & 48.25 & 41.7 & 35.11 & 28.44 & 22.14 \\
\hline $\begin{array}{l}\text { displacement increases } \\
\text { /mm }\end{array}$ & 6.55 & 6.59 & 6.67 & 6.3 & - \\
\hline test displacement /mm & 49.61 & 45.82 & 40.26 & 33.44 & 27.49 \\
\hline
\end{tabular}

The results of the electromagnetic forming experiments and simulation of the aluminum alloy sheets with different voltages were compared and analyzed. Table 3 shows the experimental and simulation results of the sheet-forming depth at different voltages. The sheet ex-

Figure 5: Outline of plate forming experiment and simulation: a) $4 \mathrm{kV}$, b) $3 \mathrm{kV}$

pansion depth increased linearly with the increase in the voltage. The errors of the experimental and simulation results decreased gradually with the increase in the voltage. The deformation profile of the sheet material was compared and analyzed at voltages of $4 \mathrm{kV}$ and $3 \mathrm{kV}$. Figure 5 illustrates the experimental and simulation results. The results showed a certain error between the simulation and experimental results. The errors were approximately $2.7 \%$ at $4 \mathrm{kV}$ and $4.45 \% 3 \mathrm{kV}$. The deformation results of the experiment were larger than those of the simulation. This result may be due to the errors of current load, friction coefficient, and constitutive relationship model. Figure 6 shows the thickness distribu-

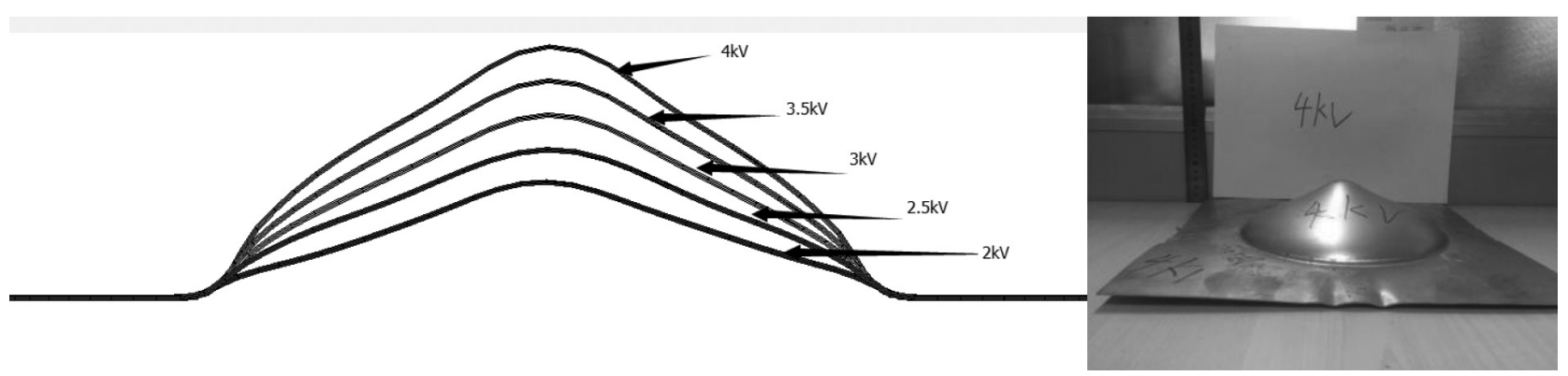

Figure 4: Displacement distribution of electromagnetic expansion sheets and simulation results under different voltages 

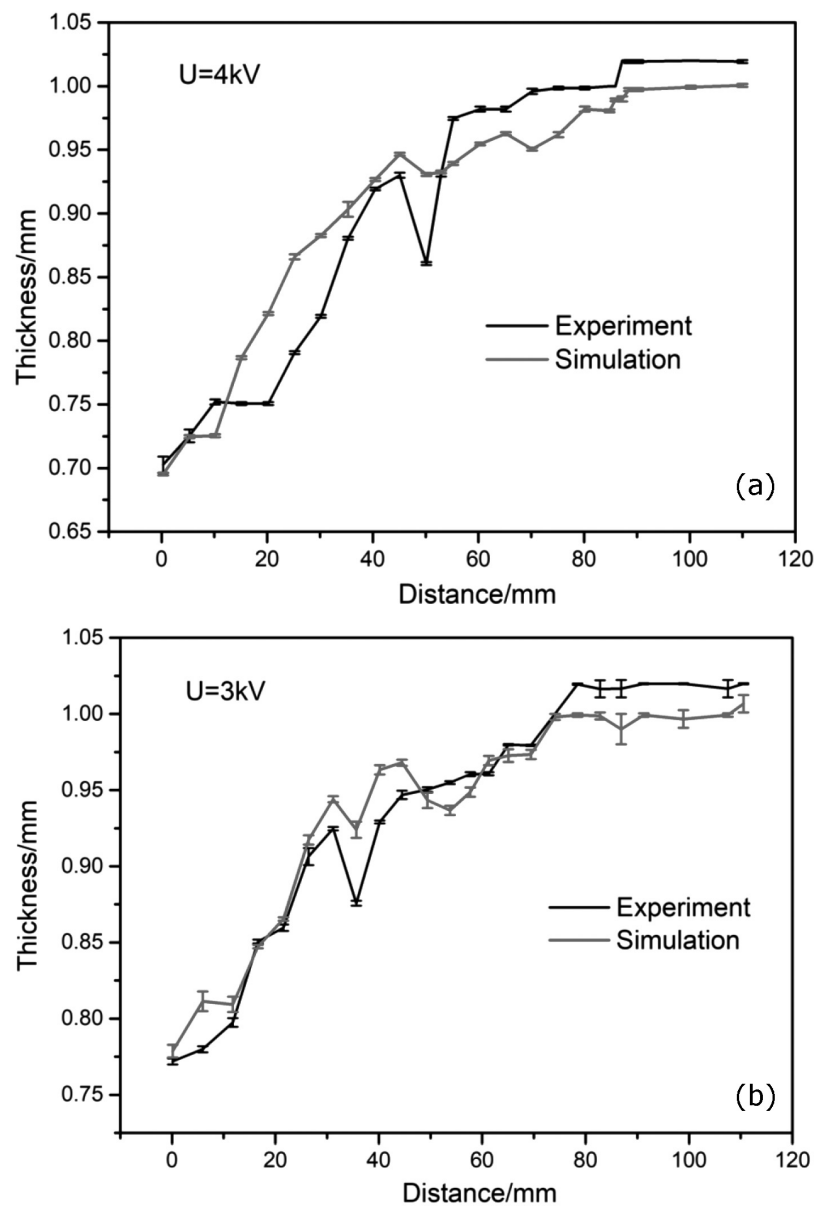

Figure 6: Thickness distribution of plate-forming experiment and simulation: a) $4 \mathrm{kV}$, b) $3 \mathrm{kV}$

tion of the sheet-forming experiment and the simulation. This result showed that the thickness results of the simulation were close to the experimental findings. The maximum thickness of the sheet deformation area was 0.71 $\mathrm{mm}$ in the experiments and $0.696 \mathrm{~mm}$ in the simulation at $4 \mathrm{kV}$. The maximum thickness of the sheet deformation area was 0.77 and $0.789 \mathrm{~mm}$ in the experiment and simulation, respectively at $3 \mathrm{kV}$.

The forming performance of the AA6014 aluminum alloy plate with different high strain rates was studied. The strain rate gradually increased with the voltage, and the forming performance of the aluminum alloy sheet gradually improved. The analysis results are as follows.

1) Compared with the quasistatic rate, the plastic performance of the aluminum alloy sheet with high strain rate significantly increased. ${ }^{21}$

2) The forming performance of the aluminum alloy sheet increased with the strain rate under the influence of high-speed load inertia under the high strain rate. $^{22}$

3) An adiabatic phenomenon was generated by highspeed deformation of the aluminum alloy sheet. ${ }^{23}$

The adiabatic temperature generated in an instant increased with the increase in the strain rate, thereby im- proving the plastic forming performance of the aluminum alloy sheet. ${ }^{24}$

\section{CONCLUSIONS}

1) The results of the electromagnetic forming test and the simulation of the aluminum alloy sheet were compared and analyzed. The test results were close to the simulation findings. The depth test result was 49.608 $\mathrm{mm}$, whereas the corresponding simulation result was $48.25 \mathrm{~mm}$. The minimum thickness test result was 0.71 $\mathrm{mm}$, and the simulation result was $0.696 \mathrm{~mm}$ at $4 \mathrm{kV}$ voltage.

2) The bulging results of the aluminum alloy sheet with different strain rates were obtained by changing the voltage. The maximum plastic deformation velocity, maximum strain rate, and forming depth of the aluminum alloy sheet gradually increased, while the minimum thickness gradually decreased with the increase in voltage.

3) The results showed that the plastic deformation performance of the aluminum alloy increased with the strain rate within a certain range of high strain rates. The findings also provide theoretical guidance for the development of a new forming process and the application of the electromagnetic forming technology of aluminum alloy sheets.

\section{Acknowledgment}

This study was financially supported by International Science and Technology Cooperation Programme (No.2015DFR710-80), Natural Science Research Program in colleges and universities of Anhui Province (No. KJ2018A0553, Scientific Research fund for talents of Hefei University (No. 18-19RC51).

\section{REFERENCES}

${ }^{1}$ H. Jurgen, Aluminium in innovative light-weight car design, Materials Transactions, 52 (2011), 818-824, doi:10.2320/matertrans.LMZ201132

${ }^{2}$ W. Y. Ma, B. Y. Wang, L. Fu, J. Zhou, M. D. Huang, Effect of friction coefficient in deep drawing of AA6111 sheet at elevated temperatures, Transactions of Nonferrous Metals Society of China, 25 (2015), 2342-2351, doi:10.1016/S1003-6326(15)63849-3

${ }^{3}$ F. C. Salvado, F. Teixeira-Dias, S. Walley, M. L. J. Lea, J. B. Cardoso, A review on the strain rate dependency of the dynamic visco-plastic response of FCC metals, Progress in Materials Science, 88 (2017), 186-231, doi:10.1016/j.pmatsci.2017.04.004

${ }^{4}$ G. K. Dhiraj, K. D. Mahesh, K. S. Pramod, P. Rajesh, R. S. Rana, A Review on Electromagnetic Forming Process, Procedia Materials Science, 6 (2014), 520-527, doi:10.1016/j.mspro.2014.07.066

${ }^{5}$ A. V. Mamutov, S. F. Golovashchenko, V. S. Mamutov, Experimental-analytical method of analyzing performance of coils for electromagnetic forming and joining operations, Journal of Materials Processing Technology, 255 (2018), 86-95, doi:10.1016/j.jmatprotec. 2017.11.050 
${ }^{6}$ V. J. Vohnout, A Hybrid Quasi-static/Dynamic Process for Forming Large Sheet Metal Parts from Aluminium Alloys, Ph.D. Dissertation of Ohio State University, (1998), 1-199

${ }^{7}$ C. F. Li, D. H. Liu, H. P. Yu, Z. Ji, Research on formability of 5052 aluminium alloy sheet in a quasi-static-dynamic tensile process, International Journal of Machine Tools and Manufacture, 49 (2009), 117-124, doi:10.1016/j.ijmachtools.2008.10.006

${ }^{8}$ D. H. Liu, H. P. Yu, C.f. Li, Experimental Observations of Quasi-Static-Dynamic Formability in Bi axially Strained AA5052-O, Journal of Materials Engineering \& Performance, 20 (2011), 223-230, doi:10.1007/s11665-010-9676-3

${ }^{9} \mathrm{~J}$. Imbert, M. Worswick, Reduction of a pre-formed radius in aluminum sheet using Electromagnetic and conventional forming, Journal of Materials Processing technology, 212 (2012.), 1963-1972, doi:10.1016/j.jmatprotec.2012.04.020

${ }^{10}$ J. Fang, J. H. Mo, X. H. Cui, J. Li, B. Zhou, Electromagnetic pulse-assisted incremental drawing of aluminium cylindrical cup, Journal of Materials Processing Technology, 238 (2016), 395-408, doi:10.1016/j.jmatprotec.2016.07.029

${ }^{11}$ R. Smerd, S. Winkler, C. Salisbury, M. Worswick, D. Lloyd, M. Finn, High strain rate tensile testing of automotive aluminum alloy sheet, International Journal of Impact Engineering Fifth International Symposium on Impact Engineering, 32 (2005), 541-560, doi:10.1016/j.ijimpeng.2005.04.013

${ }^{12}$ J. D. Thomas, M. Seth, G. S. Daehn, J. R. Bradley, N. Triantafyllidis, Forming limits for electromagnetically expanded aluminium alloy tubes: theory and experiment, Acta Materialia, 55 (2007), 2863-2873, doi:10.1016/j.actamat.2006.12.025

${ }^{13}$ H. W. Li, S. L. Yan, M. Zhan, X. Zhang, Eddy current induced dynamic deformation behaviours of aluminium alloy during EMF Modelling and quantitative characterization, Journal of Materials Processing Technology, 263 (2019), 423-439

${ }^{14}$ W. S. Lee, Z. C. Tang, Relationship between mechanical properties and micro-structural response of 6061-T6 aluminium alloy impacted at elevated temperatures, Materials and Design, 58 (2014), 116-124, doi:10.1016/j.matdes.2014.01.053

${ }^{15}$ B. Ravindranadh, M. Vemuri, K. G. Ashok, Tensile behaviour of aluminium 7017 alloy at various temperatures and strain rates, Journal of Materials Research and Technology, 5 (2016), 190-197, doi:10.1016/j.jmrt.2015.12.002
${ }^{16}$ K. Guo, X. Lei, M. Zhan, J. Tan, Electromagnetic incremental forming of integral panel under different discharge conditions, Journal of Manufacturing Processes, 28 (2017), 373-382, doi:10.1016/j.jmapro. 2017.01.010

${ }^{17}$ P. Evandro, G. Martin, R. P. Homrich, R. Pedro, R. Rodrigo, Sheet metal electromagnetic forming using a flat spiral coil: experiments, modeling, and validation, Journal of Materials Processing Technology, 263 (2018), 408-422, doi:10.1016/j.jmatprotec.2018.08.033

${ }^{18}$ Q. X. Zhang, L. Huang, J. J. Li, F. Feng, H. Su, F. Ma, Investigation of dynamic deformation behaviour of large-size sheet metal parts under local Lorentz force, Journal of Materials Processing Technology, 265 (2018), 20-33, doi:10.1016/j.jmatprotec.2018.09.036

${ }^{19}$ P. L. Eplattenier, J. Anton, I. Caldichoury, Coupling of the EM Solver with Mechanical and Thermal Shell Elements, $13^{\text {th }}$ International LS-DYNA Conference, 2014, 1-10

${ }^{20}$ D. N. Zhang, Q. Q. Shangguan, C. J. Xie, F. Liu, A modified Johnson-Cook model of dynamic tensile behaviours for 7075-T6 aluminium alloy, Journal of Alloys and Compounds, 619 (2015), 186-194, doi:10.1016/j.jallcom.2014.09.002

${ }^{21}$ S. L. Yan, H. Yang, H. W. Li, X. Yao, Variation of strain rate sensitivity of an aluminum alloy in a wide strain rate range: mechanism analysis and modeling, Journal of Alloys and Compounds, 688 (2016), 776-786 doi:10.1016/j.jallcom.2016.07.077

${ }^{22}$ A. A. Tiamiyu, R. Basu, A. G. Odeshi, J. A. Szpunar, Plastic deformation in relation to microstructure and texture evolution in AA 2017-t451 and AA 2624-t351 aluminium alloys under dynamic impact loading, Materials Science and Engineering: A, 636 (2015), 379-388, doi:10.1016/j.msea.2015.03.113

${ }^{23}$ Z. X. Zheng, D. Z. Zhu, Microstructure Characteristic of Adiabatic Shear Bandin 55vol\% TiB2 Particles Reinforced Aluminum Matrix Composite at High Strain Rates, Mechanical engineering material, 41 (2017), 84-88

${ }^{24}$ Y. Z. Guo, Q. C. Ruan, S. G. Zhu, Q. Wei, H. Chen, J. Lu, B. Hu, X. Wu, Y. L. Li, D. Fang, Temperature Rise Associated with Adiabatic Shear Band: Causality Clarified, Physical Review Letters, 122 (2019), 1-5, doi:10.1103/physrevlett.122.015503 